\title{
Transcription factor activity of estrogen receptor $\alpha$ activation upon nonylphenol or bisphenol $A$ treatment enhances the in vitro proliferation, invasion, and migration of neuroblastoma cells
}

\author{
This article was published in the following Dove Press journal: \\ OncoTargets and Therapy \\ 13 June 2016 \\ Number of times this article has been viewed
}

Hongda Ma'
Yao Yao
Changli Wang'
Liyu Zhang
Long Cheng
Yiren Wang'
Tao Wang'
Erguang Liang
Hui Jia'
Qinong Ye
Mingxiao Hou'
Fan Feng'
'Department of Pharmacy, General
Hospital of Shenyang Military Area
Command, Shenyang, ${ }^{2}$ Department
of Pharmacy, Women \& Infants
Hospital of Zhengzhou, Zhengzhou,
${ }^{3}$ Shaanxi Institute of Pediatric Disease,
Xi'an Children's Hospital, Xi'an,
${ }^{4}$ Institute of Biotechnology, Chinese
Military Medical Science Academy,
Beijing, ${ }^{5}$ School of Life Science,
Shenyang Pharmaceutical University,
Shenyang, ${ }^{6}$ Institute of Toxicology
and Pharmacology, Chinese Military
Medical Science Academy, Beijing,
People's Republic of China

Correspondence: Fan Feng; Mingxiao Hou

Department of Pharmacy, General Hospital of Shenyang Military Area Command, No 83 Wenhua Road, Shenhe District, Shenyang I I00 I6, Liaoning, People's Republic of China Tel/fax +86242885 I750

Email fengfanbio@।26.com; Houmingxiaol88@|26.com

\begin{abstract}
Many kinds of endocrine-disrupting chemicals (EDCs), for example, the environmental estrogens bisphenol A and nonylphenol, may regulate the activity of estrogen receptor $\alpha(\mathrm{ER} \alpha)$ and therefore induce potential disruption of normal endocrine function. However, the involvement of EDCs in human cancers, especially in endocrine-related cancer neuroblastoma regulation, is not very clear. In this work, results showed that upon bisphenol A or nonylphenol treatment, the transcription factor activity of $\mathrm{ER} \alpha$ was significantly increased in neuroblastoma cell line SH-SY5Y. Bisphenol A and nonylphenol could enhance ER $\alpha$ activity via recruiting it to the target gene promoter. Furthermore, treatment of bisphenol A and nonylphenol enhanced the in vitro proliferation, invasion, and migration ability of neuroblastoma cells. By investigating the role of EDC-induced ER $\alpha$ upregulation, our data extend the understanding of the function of EDCs and further suggest that ER $\alpha$ might be a potential therapeutic target in human neuroblastoma treatment.
\end{abstract}

Keywords: neuroblastoma, endocrine-disrupting chemicals, environmental estrogens, bisphenol A and nonylphenol, proliferation and metastasis

\section{Introduction}

It is well known that estrogen receptor $\alpha(\mathrm{ER} \alpha)$ mediates the development and progression of human endocrine-related cancers, for example, breast cancer and ovarian cancer. ${ }^{1}$ ER $\alpha$ contains an $\mathrm{N}$-terminal ligand-independent activation function domain 1 (AF-1), a C-terminal activation function 2 (AF-2), and a DNA-binding domain (DBD) in between. ${ }^{2}$ In the cell nucleus, ER $\alpha$ binds to the estrogen-responsive element (ERE) of its target genes and mediates their expression under stimulation of the agonists, that is, estrogen. ${ }^{2,3}$ Although the functions and detailed mechanisms of ER $\alpha$ in breast cancer have been fully studied, the involvement of ER $\alpha$ in some other kinds of human cancer, for example, hepatocellular carcinoma or neuroblastoma, is not very clear. ${ }^{4}$ Egloff et $\mathrm{al}^{5}$ showed that interaction between epidermal growth factor receptor and $\mathrm{ER} \alpha$ would participate in esophageal cancer and neck squamous cell carcinoma or lung cancer regulation. Recently, ectopic expression of ER $\alpha$ has been identified in neuroblastoma clinical specimens and it could regulate neuroprotection and proliferation of neuroblastoma by cross talking with Insulin-like growth factor 1 receptor (IGF-1R). ${ }^{6,7}$ Neuroblastoma is the most common solid tumor of children under 5 years of age. ${ }^{8-10}$ Although therapies, for example, surgery, chemotherapy, or 
radiotherapy, have improved the survival rate in patients with neuroblastoma, the treatment-related complications have also increased..$^{8-10}$ Thus, it is still urgent to develop and discover new targets for neuroblastoma treatment. Our previous work revealed that ER $\alpha$ would participate in the metastasis of neuroblastoma via interacting with transcription factor ETS-1 (E26 transformation-specific sequence 1), which belongs to ETS protein family. ${ }^{11}$ However, the detailed function of ER $\alpha$ in neuroblastoma cells needs to be further identified.

Suffering aggravation of aging or environmental contamination, a public health problem is the potential disruption of normal endocrine function caused by endocrine-disrupting chemicals (EDCs), which are a series of natural and synthetic industrial chemicals, environmental pollutants, or pesticides. ${ }^{12,13}$ Some kinds of EDCs, the environmental estrogens, for example, bisphenol A and nonylphenol, would disrupt the development of male secondary sexual characteristics or development of endocrine system. ${ }^{12-16}$ However, the involvement of EDCs in human cancers, especially endocrine-related human cancers, in neuroblastoma, is almost unknown. Recently, Li et al, ${ }^{13}$ Zhang et al, ${ }^{16}$ and Huang et $\mathrm{al}^{15}$ identified potential $\mathrm{ER} \alpha$ agonist from EDCs via examining the transcription factor activity of ER $\alpha$ or detecting the affinity between candidate compounds to the ligandbinding domain from ER $\alpha$. Our previous results also reveal that bisphenol A and nonylphenol are potential agonists of $\mathrm{ER} \alpha$ and enhance ER $\alpha$-EGFP nuclear granule formation in a dose-dependent manner. ${ }^{17}$ These works mainly focus on the recognition or screening of environmental estrogens, and to unmask the mechanism by which EDCs regulate ER $\alpha$ and further affect endocrine-related cancer physiology, more studies should be done in the future.

In this study, we found that bisphenol A and nonylphenol induce transcription factor activity of ER $\alpha$ in neuroblastoma cell. Bisphenol A- and nonylphenol-mediated ER $\alpha$ activation significantly promotes neuroblastoma cell proliferation, migration, and invasion. Our data reveal the endocrinerelated feature of neuroblastoma and suggest that ER $\alpha$ might be a potential therapeutic target in human neuroblastoma treatment.

\section{Materials and methods Plasmids}

The vectors of ER $\alpha$ or its small interfering RNA (siRNA) were obtained from Origene Company, Maryland, USA. Luciferase reporter genes, catD-Luc (cathepsinD-Luc), and ERE-Luc were gifts from Dr Qinong Ye and described earlier. ${ }^{3,18}$ All vectors were confirmed by DNA sequencing.

\section{Cell culture and reagents}

E2 (endogenous agonist of ER $\alpha, 17-\beta$-estradiol) and ICI182780 (antagonist of ER $\alpha$ ) were from Sigma Aldrich Co. (St Louis, MO, USA); bisphenol A (Acros Organics, Belgium) and nonylphenol (AccuStandard, New Haven, CT, USA) were used. Human neuroblastoma SH-SY5Y (ER $\alpha$ positive) and breast cancer MDA-MB-231 (ER $\alpha$ negative) cells were from cell resources center of the Chinese Academy of Medical Sciences and Peking Union Medical College (Beijing, People's Republic of China). Cells were cultured in Dulbecco's Modified Eagle's Medium (DMEM; Thermo Fisher Scientific, Waltham, MA, USA) at $37^{\circ} \mathrm{C}$ with $5 \% \mathrm{CO}_{2}$.

\section{Luciferase assay}

SH-SY5Y and MND-MB-231 cells were seeded in 24-well plates (Corning Incorporated, Corning, NY, USA) in phenol red-free DMEM (Thermo Fisher Scientific) supplemented with $0.5 \%$ charcoal-stripped fetal bovine serum (FBS; Hyclone, Logan, Utah, USA). Transfection was performed using Lipofectamine 2000 (Thermo Fisher Scientific). Cells were cotransfected with luciferase reporters and then harvested for analysis of luciferase and $\beta$-galactosidase activities following protocols descripted by Zhang et al. ${ }^{1}$ Results were shown as mean \pm SD from three independent experiments with similar results.

\section{Antibodies and Western blot}

Antibodies against ER $\alpha$, cyclin D1 (CCND1), and GAPDH were obtained from Santa Cruz Biotechnology Inc. (Dallas, TX, USA). A polyclonal anti-rabbit IgG antibody conjugated with the horseradish peroxidase were from Sigma-Aldrich Co. SH-SY5Y or MDA-MB-231 cells were seeded and cultured in six-well plates (Corning Incorporated). The cells, which were treated with indicated concentration compounds or transfected with vectors, were harvested by Radio-Immunoprecipitation Assay (RIPA) buffer supplemented with protease inhibitor cocktails (Sigma-Aldrich Co.). Total protein samples were performed by sodium dodecyl sulfate-polyacrylamide gel electrophoresis and transprinted to polyvinylidene fluoride membranes (EMD Millipore, Billerica, MA, USA). Then, the membranes were blocked with $10 \%$ bovine serum albumin in Tris buffered saline with Tween 20 (TBST) buffer and then incubated for 2 hours at $37^{\circ} \mathrm{C}$ with rabbit primary antibody against human ER $\alpha$ (1:2,000), rabbit primary antibody against cyclin D1 $(1: 1,000)$, and mouse primary monoclonal antibody against human GAPDH $(1: 5,000)$ diluted in TBST containing 5\% bovine serum albumin and subsequently washed three times 
in TBST for 5 minutes each. Then, the membranes were incubated with the horseradish peroxidase-conjugated secondary antibodies $(1: 5,000)$ after washing three times in TBST for 5 minutes each. At last, the blot was developed with enhanced chemiluminescence reagents (Thermo Fisher Scientific) by X-ray films. The blots were performed on three independent occasions with similar results.

\section{Chromatin immunoprecipitation}

The recruitment of ER $\alpha$ to its DNA-binding elements was analyzed by chromatin immunoprecipitation (ChIP) assays as protocols, as described previously. ${ }^{19,20}$ SH-SY5Y cells, which were treated with solvent control (1\%o dimethyl sulfoxide) or indicated concentration compounds for 1 hour, were fixed by adding formaldehyde to the medium. After cross-linking, glycine was added at a final concentration of $125 \mathrm{mmol} / \mathrm{L}$, and the cells were harvested with lysis buffer. The cell nuclei subfractions were pelleted by centrifugation and resuspended in nuclear lysis buffer. The nuclear lysates were sonicated to generate DNA fragments of $0.5-1 \mathrm{~kb}$, and then ChIP assays were performed with antibodies against ER $\alpha$. Real-time polymerase chain reaction amplification was performed with DNA extracted from the ChIP assay and primers flanking the ER $\alpha$-binding elements in promoter region of cathepsin $\mathrm{D}$ (CTSD) gene.

The primers used in ChIP analysis were as follows: CTSD genes promoter forward: $5^{\prime}$-GGTTTCT CTGGAAGCC CTGTAG-3'; reverse:5'-GTTTGCACCCGGACCGGTCAC-3'; input genomic DNA forward: 5'-GTGTCTGTCTGCTCGGG CTTCTGTG-3'; reverse: 5'-GCAGGTCCAAGTCACACAG GAAATG-3'.

\section{Cell proliferation assays}

Cell proliferation was analyzed by MTT assay as described previously. ${ }^{21}$ The proliferation of SH-SY5Y cells was determined using a CellTiter $96^{\circledR}$ nonradioactive cell proliferation assay kit (Promega Corporation, Fitchburg, WI, USA), according to the manufacturer's instructions. Cells, which were transfected with plasmids or treated with agents, were seeded into 96 -well plates and incubated at $37^{\circ} \mathrm{C}$ with $5 \%$ $\mathrm{CO}_{2}$. After incubating for 1 day, 2 days, 3 days, and 4 days, cells were harvested and analyzed. Finally, growth curves for each cell group were drawn according to the volume of optical density (OD) $490 \mathrm{~nm}$ from a 96-well plate reader. The MTT cell growth assays were performed for three independent times with similar results. For colony formation, SH-SY5Y cells were seeded in six-well plates (500 cells per well). After culturing for 2-3 weeks, colonies were fixed by $3 \%$ paraformaldehyde and stained by crystal violet $(0.5 \%$ diluted in $20 \%$ ethanol). Finally, colonies were harvested and the absorbance was measured at $546 \mathrm{~nm}$.

\section{Anchorage-independent growth assay}

SH-SY5Y cells were treated with agents. Cells were plated on six-well plates (500 per well) (Corning Incorporated), with a bottom layer of $0.7 \%$ low-melting-temperature agar in DMEM and a top layer of $0.25 \%$ agar in DMEM. Colony number scored after 3-4 weeks of growth was shown as mean \pm SD of three independent experiments with similar results. ${ }^{22,23}$

\section{Transwell invasion and migration assay}

The invasion and migration assays were performed in 24-well plates using the transwell chamber (Corning Incorporated) fitted with a polyethylene terephthalate filter membrane with $8 \mu \mathrm{m}$ pores. For invasion assay, the membrane under surface was coated with $30 \mu \mathrm{L}$ extracellular matrix gel (BD Biosciences, San Jose, CA, USA) mixed with Roswell Park Memorial Institute 1640 (RPMI-1640) serum-free medium in $1: 5$ dilution for 4 hours at $37^{\circ} \mathrm{C}$. The top chambers of the transwells were filled with $0.2 \mathrm{~mL}$ of cells $\left(2 \times 10^{5}\right.$ cells $\left./ \mathrm{mL}\right)$ in serum-free medium, and the bottom chambers were filled with $0.25 \mathrm{~mL}$ of RPMI-1640 medium containing 10\% FBS. The cells were incubated in the transwells at $37^{\circ} \mathrm{C}$ in $5 \% \mathrm{CO}_{2}$ for 4 hours (for migration) or 24 hours. ${ }^{24}$ Finally, invading or migrating cells were fixed and stained with critical violet ( $0.5 \%$ diluted in $20 \%$ ethanol). The migration or invasion cells were harvested by glacial acetic acid and measured using a multifunctional microplate reader at $546 \mathrm{~nm}$. Relative migration/invasion cell number was calculated as (administration group OD $546 \mathrm{~nm}) /($ control group OD $546 \mathrm{~nm})$. Similar results were obtained from three independent experiments.

\section{Ethics statement}

Our studies are in compliance with the Declaration of Helsinki and were permitted by the Ethics Committee of the General Hospital of Shenyang Military Area Command. Our work aims to declare the cross talk between transcriptional factors and the underlying molecular mechanisms. We did not use any materials from clinical specimens. And the methods did not relate to the clinical trial or methods. Only the cell lines used in this work were obtained from the typical biological sample preservation center but not clinical specimens, human subjects, human material, or data.

\section{Statistical analysis}

The results obtained from polymerase chain reaction were analyzed by the Alpha Innotech analysis software (San 
Leandro, CA, USA). The relative expression level was calculated as follows: (indicated group protein expression level/loading control expression level)/(control group protein expression level/loading control expression level). All statistical significant analyses were performed using SPSS 9.0 (SPSS Inc., Chicago, IL, USA) statistical software. $P$-value of $<0.05$ was considered statistically significant. Statistical significance in the luciferase activity and cell growth assays was analyzed by Bonferroni correction with or without two-way analysis of variance. The median effective concentration $\left(\mathrm{EC}_{50}\right)$ values of bisphenol A and nonylphenol on transcription factor activity of ER $\alpha$ were calculated by Origin 6.0 software (OriginLab Corporation, Hampton, Massachusetts, USA).

\section{Results}

\section{Bisphenol A and nonylphenol induce the transcription factor activity of ER $\alpha$}

To study the role of EDCs in regulating transcription factor activity of $\mathrm{ER} \alpha$, bisphenol $\mathrm{A}$ and nonylphenol were used for luciferase-based reporter gene assay. SH-SY5Y cells were cotransfected with ERE-Luc (Figure 1A and B) or catD-Luc (Figure 1C and D) reporters. Our results showed that bisphenol A and nonylphenol increase the activity of
$\mathrm{ER} \alpha$ in a dose-dependent manner (Figure 1). The $\mathrm{EC}_{50}$ value is $0.43 \pm 0.11 \mu \mathrm{mol} / \mathrm{L}$ or $0.58 \pm 0.25 \mu \mathrm{mol} / \mathrm{L}$, respectively. Next, bisphenol A (Figure 2A) and nonylphenol (Figure 2B) enhanced the protein level of cyclin D1, an ER $\alpha$-responsive gene, in a dose-dependent manner. These results indicated that bisphenol A and nonylphenol induced the transcription factor activity of $\mathrm{ER} \alpha$ and the expression of downstream target gene of ER $\alpha$.

\section{The specificity of bisphenol $A$ and nonylphenol in regulating ER $\alpha$ activity}

To study the specificity of bisphenol A and nonylphenol in regulating ER $\alpha$ activity, breast cancer MDA-MB-231 cells, which lack ER $\alpha$ (Figure 3), were used for ER $\alpha$ overexpression. In the presence of bisphenol A and nonylphenol, overexpression of $\mathrm{ER} \alpha$, but not empty vector, mediated the elevated activity of luciferase gene reporters (Figure $3 \mathrm{~A}$ and B). SH-SY5Y cells, which express ER $\alpha$, were transfected with control siRNA or ER $\alpha$ siRNA for protein knockdown (Figure 3C and D). Reduction of endogenous $\mathrm{ER} \alpha$ dramatically decreased the effect of bisphenol A- and nonylphenol-induced ERE-Luc and catD-Luc reporters activity (Figure 3C and D); the inhibition rate is $82.67 \%$ and $76.89 \%$, respectively.
A
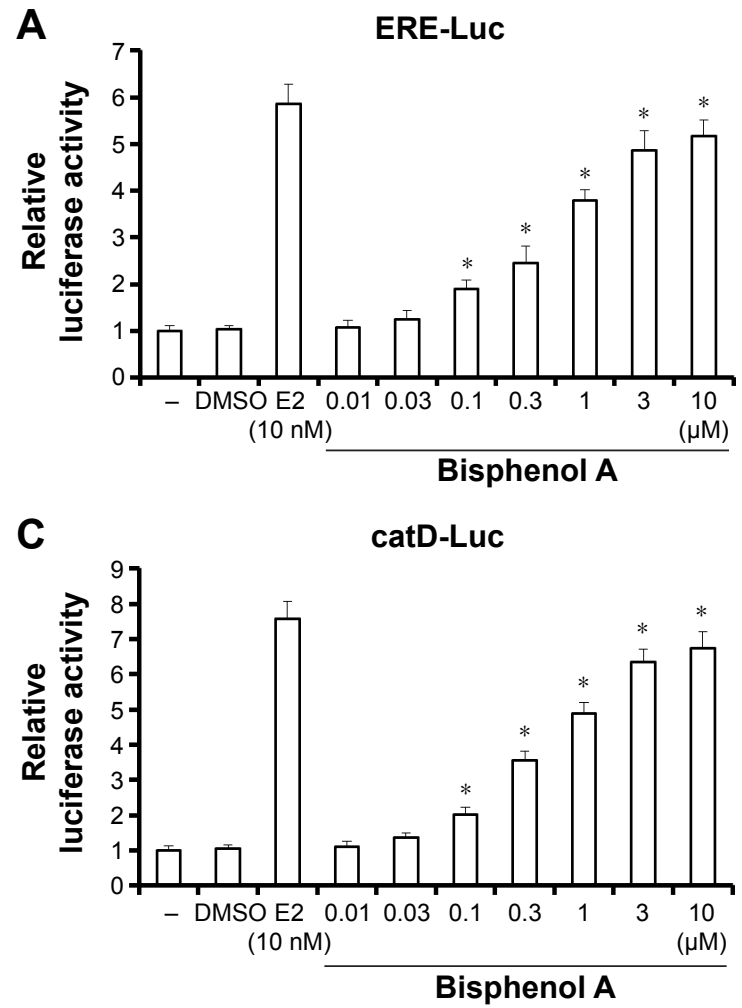

B
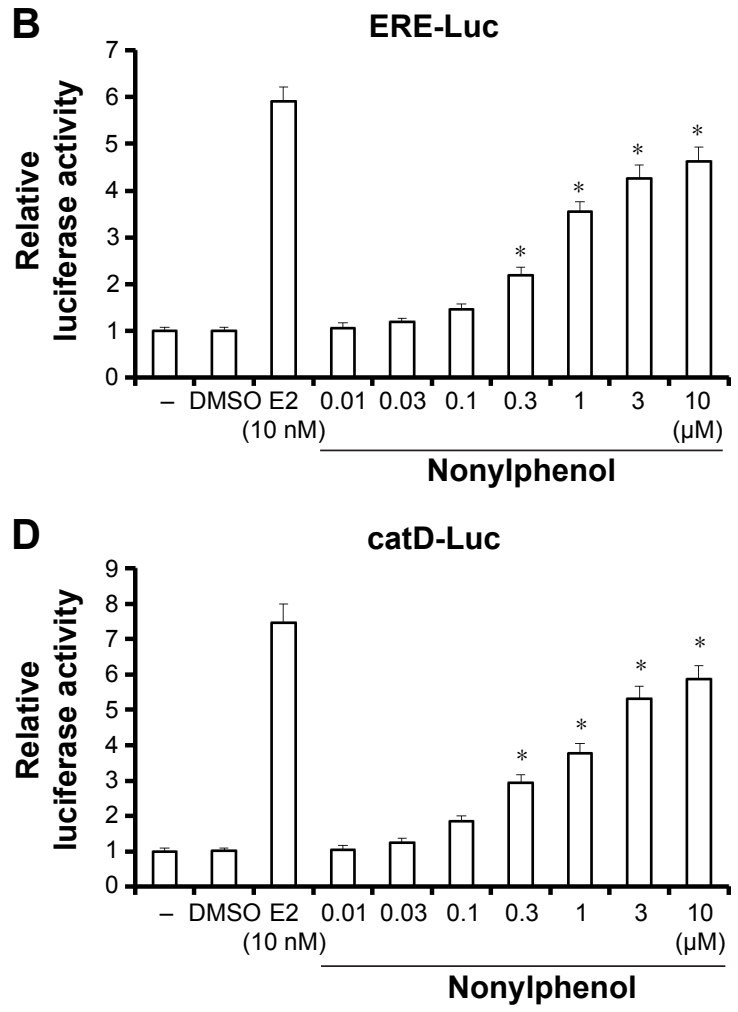

Figure I Bisphenol A or nonylphenol induces $E R \alpha$ transcriptional activity.

Notes: SH-SY5Y cells, which were transfected with ERE (A and B) or catD (C and D) reporters, were treated with indicated concentration of bisphenol A (A and C) or nonylphenol (B and D). The I\%. DMSO was used as a solvent control, and $10 \mathrm{nmol} / \mathrm{L}$ E2 was chosen as a positive control. Then, the cells were harvested and determined by the luciferase assays after 24 hours treatment. "-" represents the negative control. The values are the mean \pm SD from three independent experiments. $* P<0.05$.

Abbreviations: ER $\alpha$, estrogen receptor $\alpha$; ERE, estrogen-responsive element; DMSO, dimethyl sulfoxide; catD, cathepsinD-Luc; E2, I7- $\beta$-estradiol. 

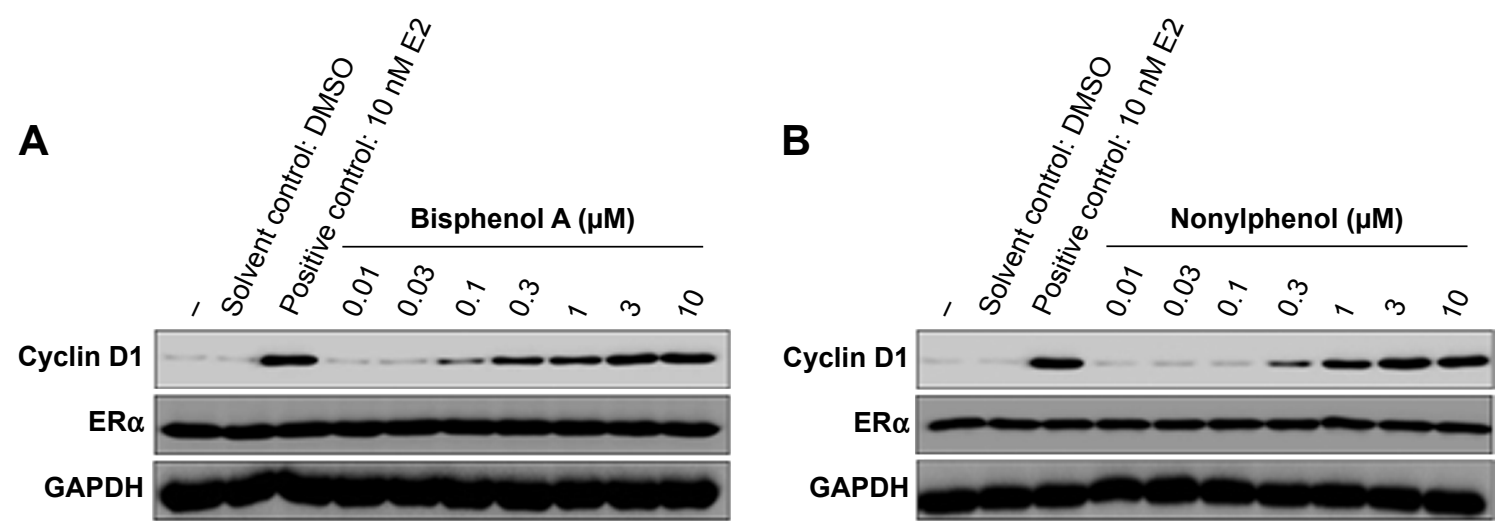

Figure 2 Bisphenol A or nonylphenol enhances the expression of ER $\alpha$ targeted gene.

Notes: SH-SY5Y cells were treated with indicated concentration of bisphenol A (A) or nonylphenol (B). The protein level of ER $\alpha$ or cyclin DI was identified by Western blot after 24 hours treatment. "-" represents the negative control.

Abbreviations: $\mathrm{ER} \alpha$, estrogen receptor $\alpha$; DMSO, dimethyl sulfoxide; E2, I7- $\beta$-estradiol.

A

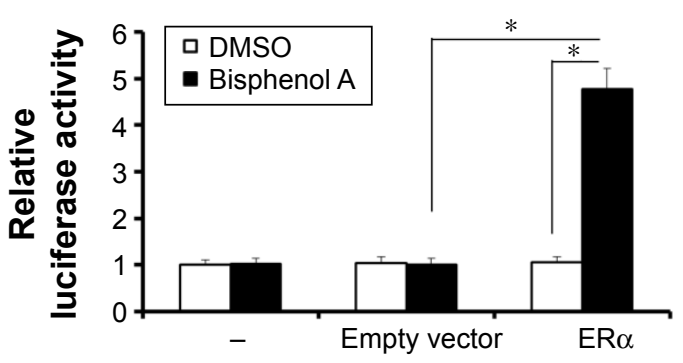

C

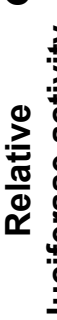

Bisphenol A DMSO

ER $\alpha$ siRNA

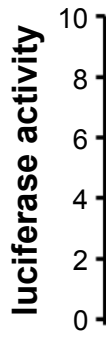

ICI

ERE-Luc

ERE-LuC

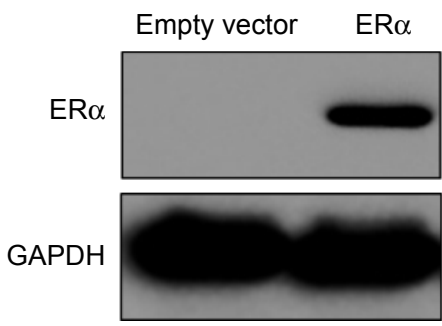

B

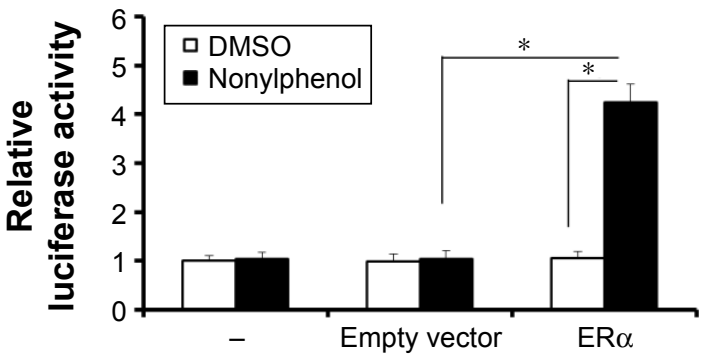

D $\quad * \quad$ ERE-Luc
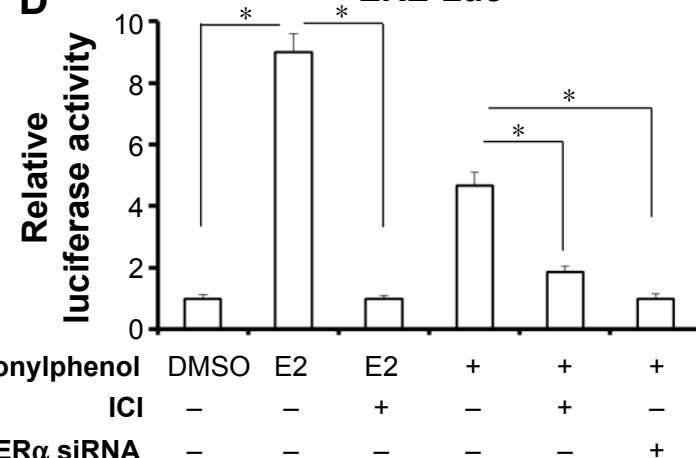

Figure 3 Bisphenol A or nonylphenol induces the activity of ERE-Luc or catD-Luc reporters via ER $\alpha$.

Notes: (A and B) MDA-MB-23I cells were transfected with empty vector or ER $\alpha$ vectors, whereas SH-SY5Y cells were transfected with control siRNA (C and D), ER $\alpha$

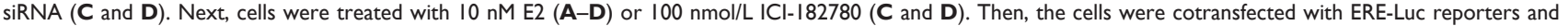
harvested for the luciferase analysis. The protein level of ER $\alpha$ was determined by Western blot, and the results are shown in the panels at the bottom of the figure. "-" represents the negative control. The values are the mean \pm SD from three independent experiments. $* P<0.05$.

Abbreviations: ERE, estrogen-responsive element; ER $\alpha$, estrogen receptor $\alpha$; siRNA, small interfering RNA; DMSO, dimethyl sulfoxide; E2, I7- $\beta$-estradiol; ICI, ICI-I82780; Luc, luciferase. 
Next, E2 (17- $\beta$-estradiol), an endogenous estrogen, was used as a positive control and ICI-182780, an inhibitor of $\mathrm{ER} \alpha$, was also employed here. The results showed that E2, bisphenol A, and nonylphenol all induced the transcription factor activity of ER $\alpha$ (Figure 3C and D). Treatment of ICI182780 almost blocks all the effects of E2, bisphenol A, and nonylphenol (Figure $3 \mathrm{C}$ and $\mathrm{D}$ ); the inhibition rate is $97.51 \%$, $98.43 \%$, and $97.64 \%$, respectively. These data indicated that ER $\alpha$ itself is required for the effect of bisphenol $\mathrm{A}$ or nonylphenol.

\section{Effect of bisphenol A and nonylphenol on the CTSD promoter recruitment of ER $\alpha$}

To further investigate the effect of bisphenol A and nonylphenol, we performed ChIP assays. As expected, bisphenol A and nonylphenol potentiated the recruitment of ER $\alpha$ and SRC-1, a co-activator of $\mathrm{ER} \alpha$, to the CTSD promoter sequence (Figure 4A) in a dose-dependent manner (Figure 4B and C). In addition, knockdown of ER $\alpha$ level or activity downregulated the recruitment of ER $\alpha$ and SRC-1 triggered by bisphenol A and nonylphenol (Figure 4D and E). These results further confirmed the effect of bisphenol A and nonylphenol inducing the transcription factor activity of $\mathrm{ER} \alpha$.

\section{Bisphenol $\mathrm{A}$ and nonylphenol increase the proliferation of $\mathrm{SH}-\mathrm{SY} 5 \mathrm{Y}$ cells}

Next, MTT, transwell, and soft agar assays were performed to detect the proliferation, invasion, migration, or anchorageindependent growth of SH-SY5Y cells. For MTT assay, SH-SY5Y cells were cultured in phenol red-free DMEM supplemented with $2 \%$ charcoal-stripped FBS (Figure 5A and D) or in DMEM added 10\% normal FBS (Figure 5B, C, $\mathrm{E}$, and F). Bisphenol A and nonylphenol markedly enhanced the proliferation of SH-SY5Y cells (Figure 5A and D), while downregulation of ER $\alpha$ activity or expression level markedly reduced the growth of SH-SY5Y cells induced by bisphenol A and nonylphenol (Figure 5B, C, E, and F).

Next, the colony formation and soft agar assays were examined. Bisphenol A and nonylphenol markedly enhanced SH-SY5Y cell colony formation (Figure 5G-I) and anchorage-independent growth (Figure 6A and B). Downregulation of ER $\alpha$ activity or expression level markedly reduced the colony formation (Figure 5G-I) and anchorage-independent growth (Figure 6A and B) of SH-SY5Y cells.

Moreover, the in vitro invasion and migration of SH-SY5Y cells were examined. Bisphenol A and nonylphenol enhanced the invasion and migration of SH-SY5Y cells (Figures 7 and 8).

A

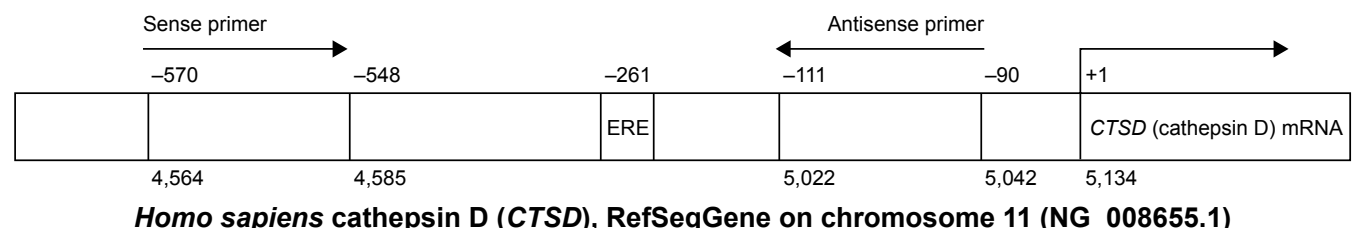

B
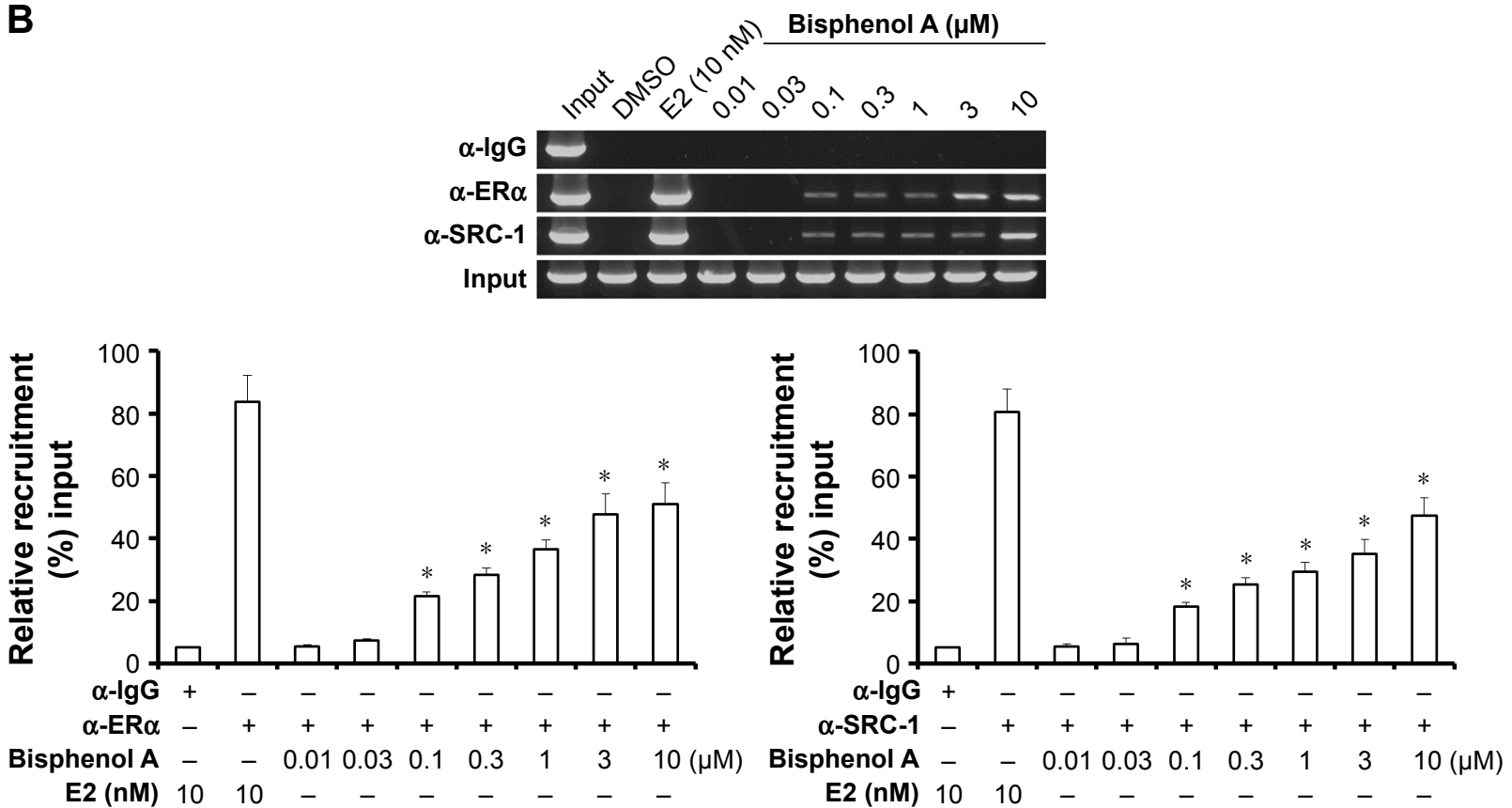

Figure 4 (Continued) 
C
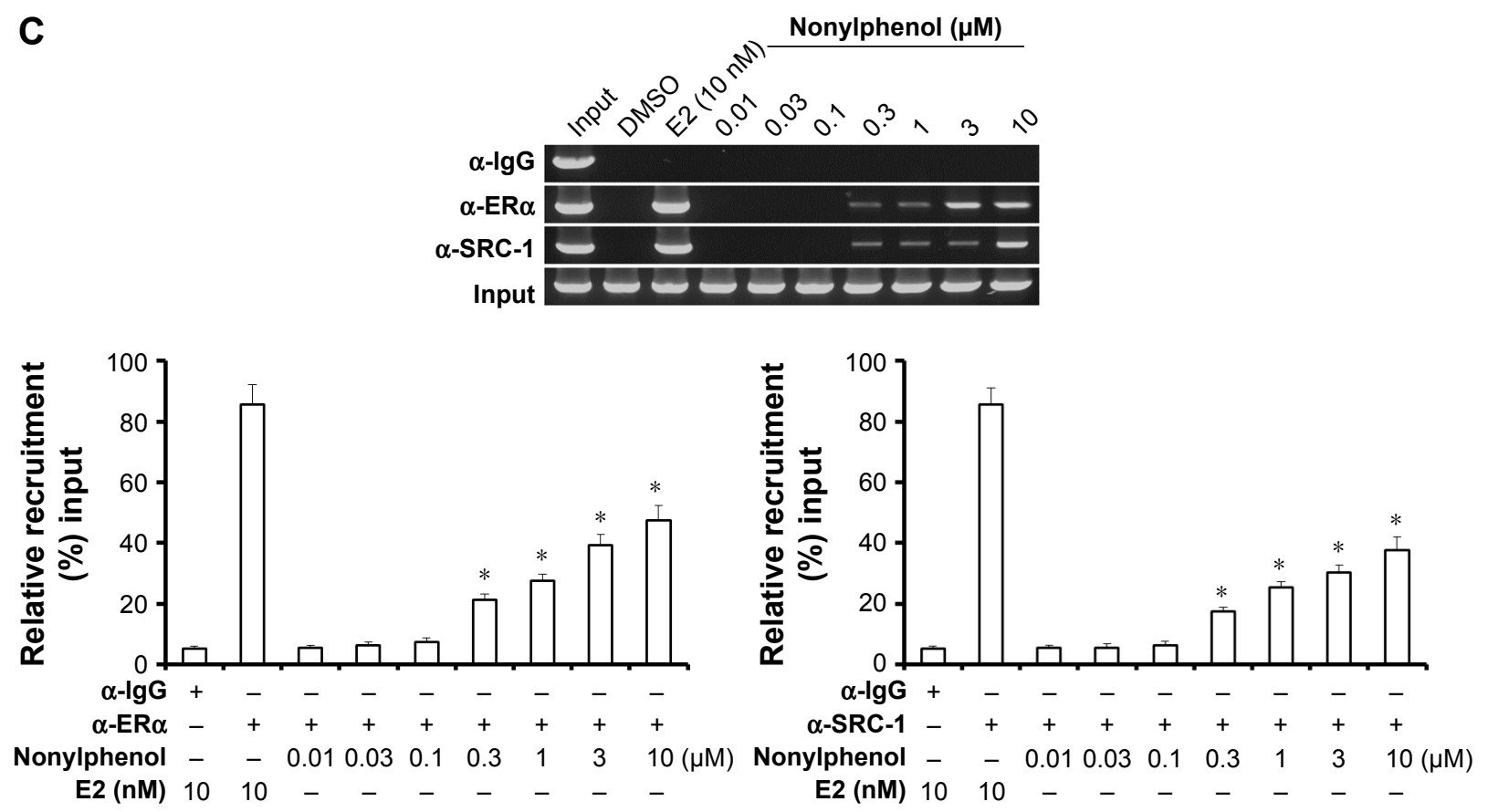

D

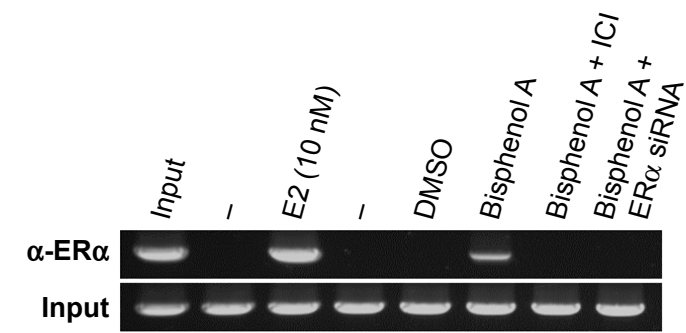

$\mathbf{E}$
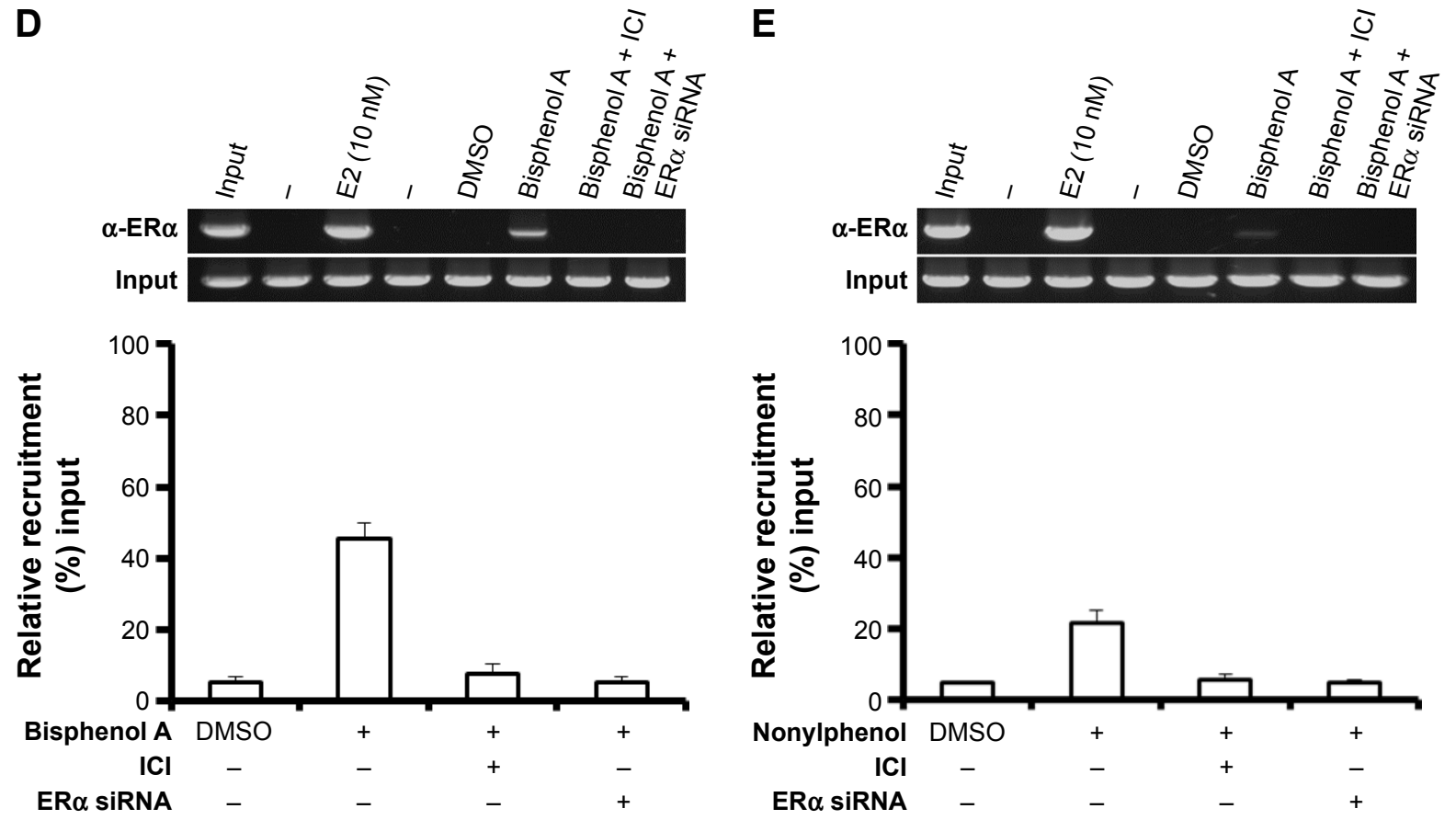

Figure 4 Bisphenol A or nonylphenol modulates the recruitment of ER $\alpha$ and transcriptional coregulator SRC-I to CTSD promoter region.

Notes: (A) Bold and italicized font indicates the proximal region of CTSD promoter containing ERE sequence. Primers used in ChIP analysis were also indicated. (B-E) SH-SY5Y cells were stimulated with bisphenol A or nonylphenol for I hour, and the recruitment of ER $\alpha$ and SRC-I to the CTSD promoter was detected by ChIP assay. (D and E) SH-SY5Y cells were transfected with ER $\alpha$ siRNA or treated with 100 nmol/L ICl-I82780. “-” represents the negative control. *P $<0.05$.

Abbreviations: ER $\alpha$, estrogen receptor $\alpha$; SRC-I, SRC-I, steroid receptor coactivator I; CTSD, cathepsin D; ERE, estrogen-responsive element; ChIP, chromatin immunoprecipitation; siRNA, small interfering RNA; mRNA, messenger RNA; DMSO, dimethyl sulfoxide; IgG, immunoglobulin G; E2, I7- 3 -estradiol; ICI, ICI-I82780.

Downregulation of ER $\alpha$ activity or expression markedly reduced the effect of bisphenol A or nonylphenol (Figures 7 and 8). Taken together, bisphenol A and nonylphenol promoted the proliferation, anchorage-independent growth, and in vitro invasion or migration of SH-SY $5 Y$ cells via ER $\alpha$.

\section{Discussion}

In this study, we identified that EDCs-ER $\alpha$ interaction-mediated neuroblastoma cell proliferation. Bisphenol A and nonylphenol treatment increased the transcription factor activity of ER $\alpha$ and the expression of the responsive genes CCND1. 


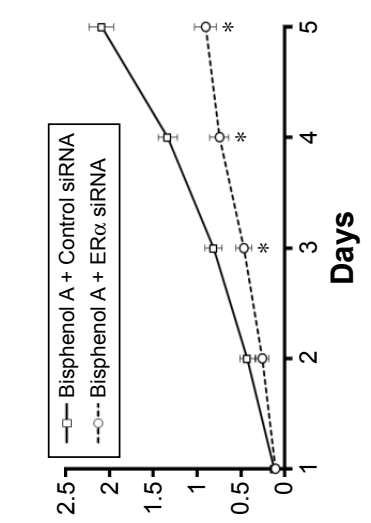

mu 06† 00 səqunu

$\checkmark$ ॥ә әм!џе|әу

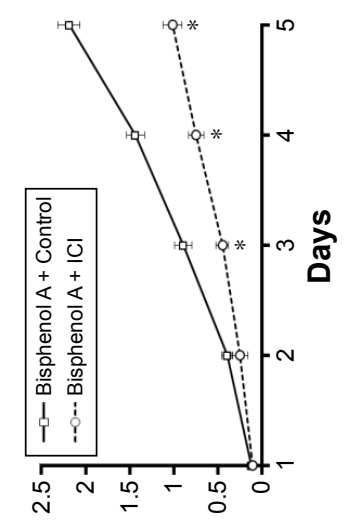

mu 06॰ 00 səqunu

m Іाәว әм!ฺерәу

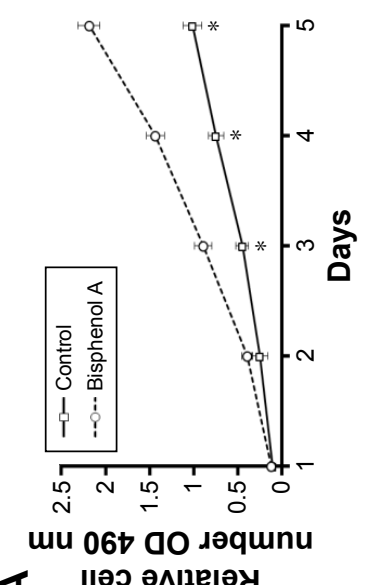

$\varangle \quad$ ॥ә0 әм!ฺејәу
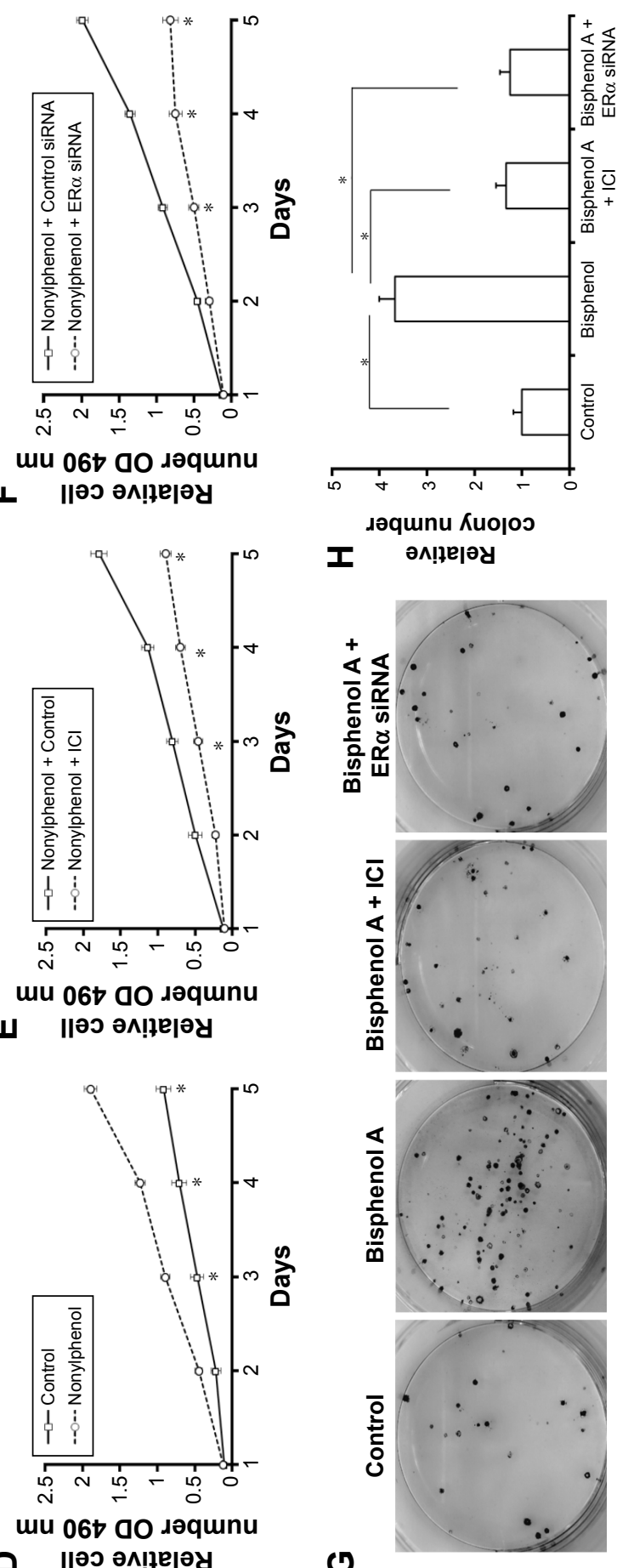

产

한

은

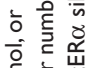

要

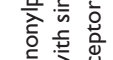

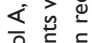

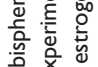

紊要

过

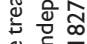

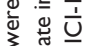

㝋韧

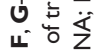

w $\mathrm{x}$ 的

$0+1$ 낭

象

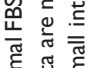

Jəqunu Kuoloo

$\neg$ әм!ฺејәу

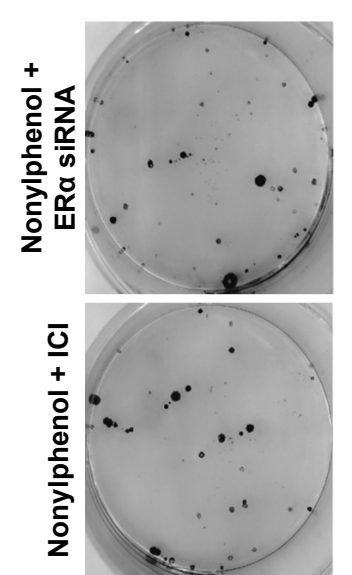

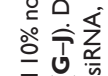

尊

原

要

잉

든

安这

䆑愈

范卢总

落高

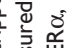

항

容

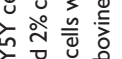

宁 密

就它察

응 $\sum_{0.4}$

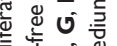

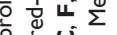

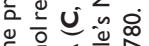

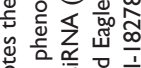

过

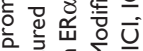

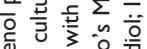

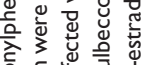

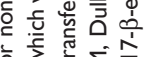

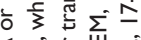

$\varangle$

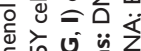

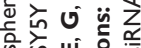

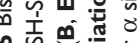

m 
A Solvent control: DMSO

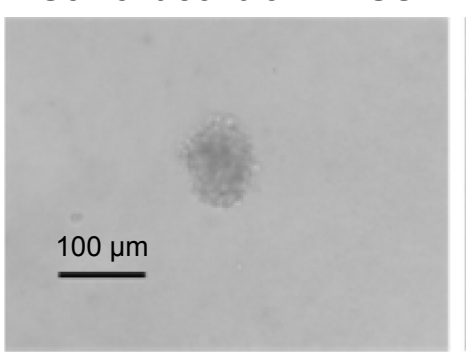

Bisphenol A + ER $\alpha$ siRNA

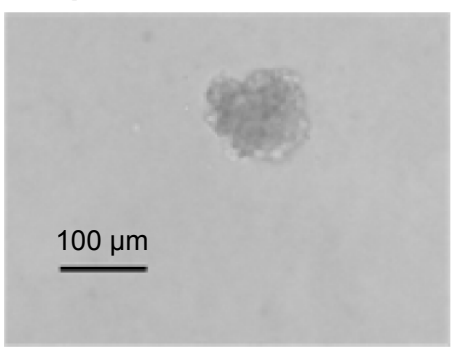

B Solvent control: DMSO

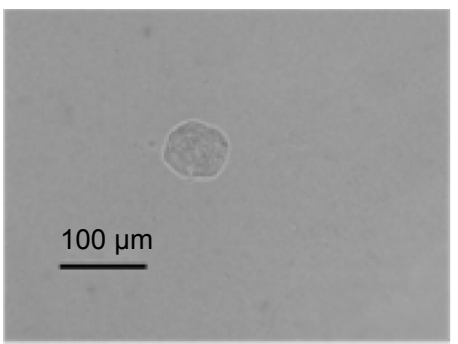

Nonylphenol + ER $\alpha$ siRNA

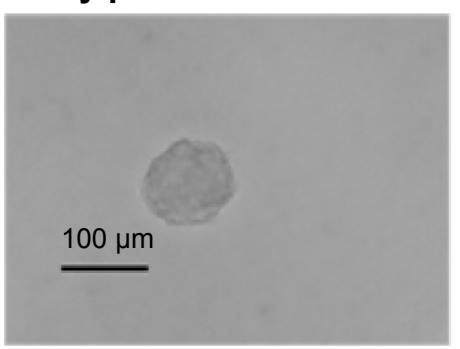

Bisphenol A

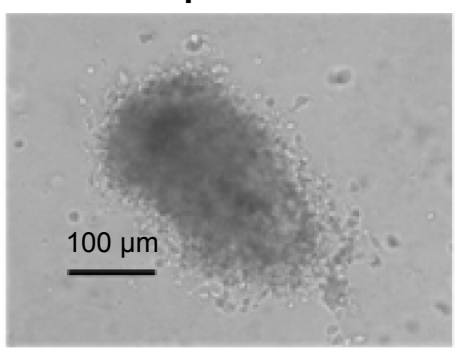

Bisphenol A + ICl-182780
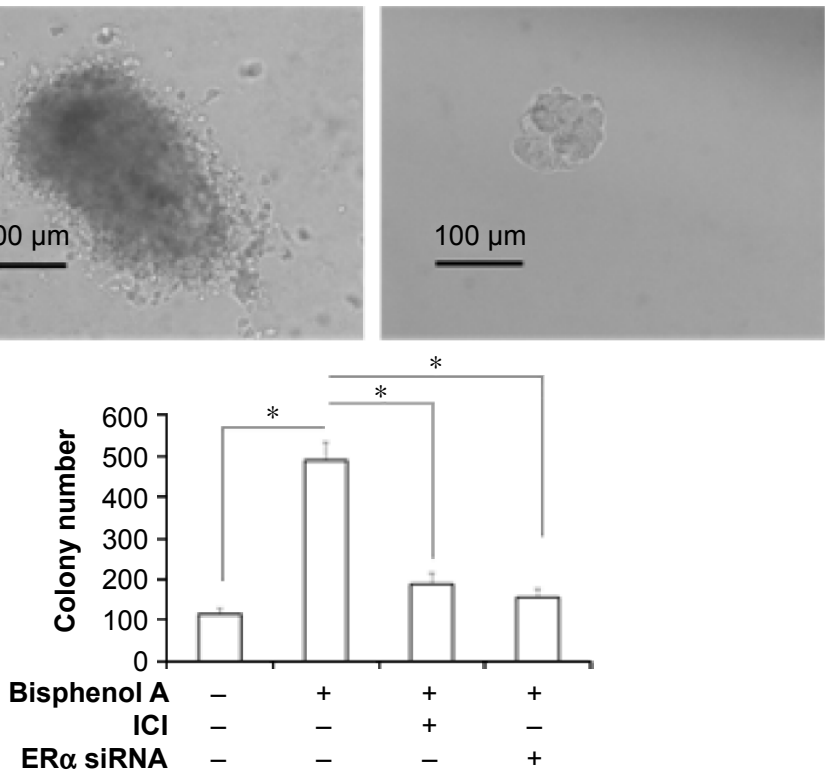

ER $\alpha$ SIRNA - $\quad-$

Nonylphenol

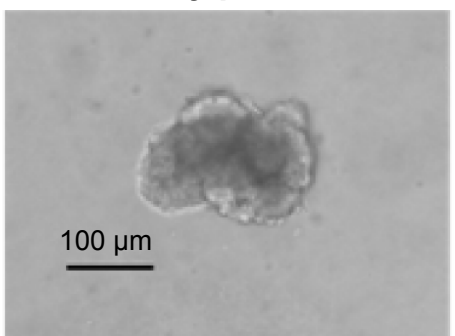

Nonylphenol + ICI-182780

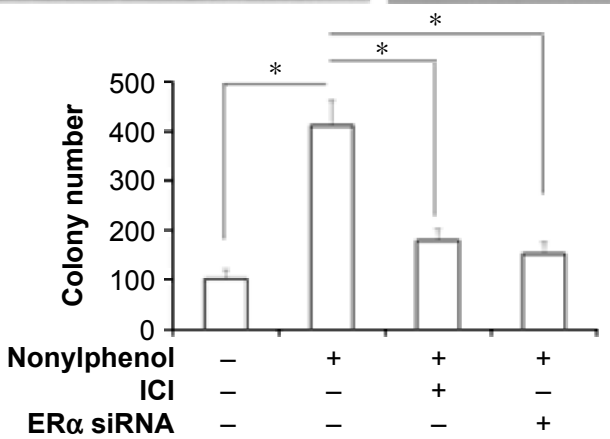

Figure 6 Bisphenol A or nonylphenol promotes the anchorage-independent growth of SH-SY5Y cells.

Notes: SH-SY5Y cells, which were treated with bisphenol A (A) or nonylphenol (B), were treated with $100 \mathrm{nmol} / \mathrm{L}$ ICl-I82780 or transfected with ER $\alpha$ siRNA. Cells were then measured by soft agar analysis. Colony is shown in the photographs. Data are mean \pm SD of triplicate independent experiments and have been repeated three times with similar numbers. $* P<0.05$. 400 $\times$ magnification.

Abbreviations: $\mathrm{ER} \alpha$, estrogen receptor $\alpha$; siRNA, small interfering RNA; DMSO, dimethyl sulfoxide; ICI, ICl-I82780.

In line with this observation, ER $\alpha$ inactivation via its antagonist or siRNA reduced the effect of bisphenol A and nonylphenol. Moreover, treating bisphenol A and nonylphenol stimulated neuroblastoma cell proliferation, migration, and invasion. Although ER $\alpha$ has been highly detected in some endocrine-related cancers, the function of $\mathrm{ER} \alpha$ needs to be further identified in addition to breast cancer. The ER $\alpha$ antagonist ICI-182780 inhibits the growth of breast cancer or glioma cells. ${ }^{25}$ Whether ER $\alpha$ plays a role in neuroblastoma development is still not clear. Our previous work identified the protein interaction between ER $\alpha$ and ETS-1 in neuroblastoma cells. ${ }^{11}$ ER $\alpha$ activation increased the transcription factor activity of ETS-1. ETS-1 is a transcription factor that has been implicated to play compensatory roles in regulating cell proliferation, metastasis, and apoptosis. ${ }^{7}$ Since $\mathrm{ER} \alpha$ is a ligand-dependent nuclear receptor, ER $\alpha$-mediated 
A Solvent control: DMSO

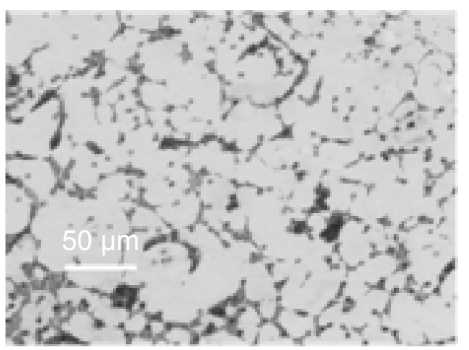

Bisphenol A + ER $\alpha$ siRNA

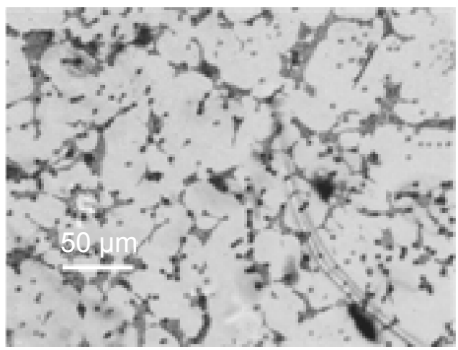

B Solvent control: DMSO

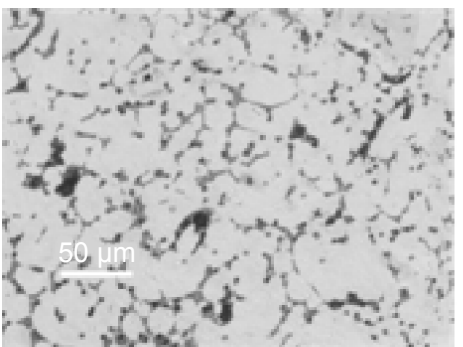

Nonylphenol + ER $\alpha$ siRNA

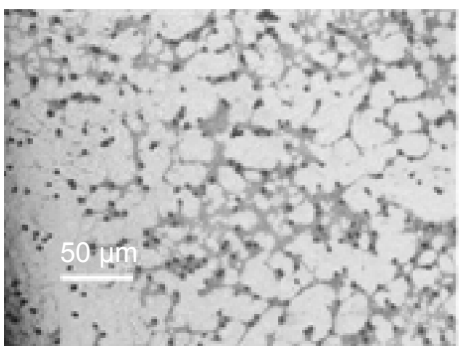

Bisphenol A

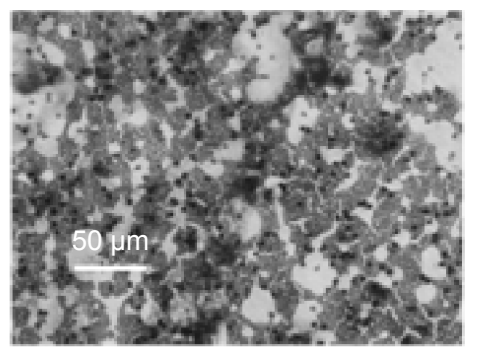

Bisphenol A + ICl-182780
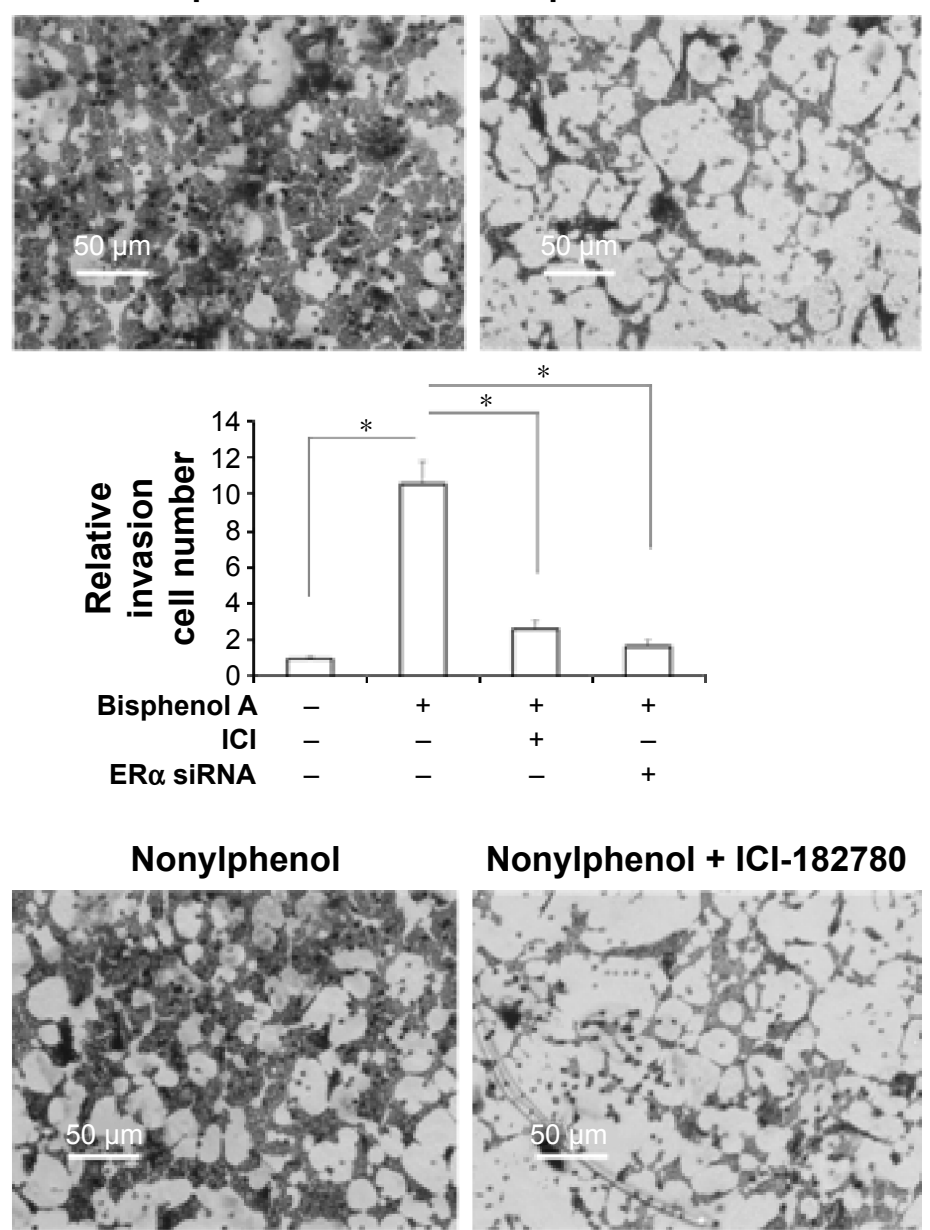

Nonylphenol + ICI-182780

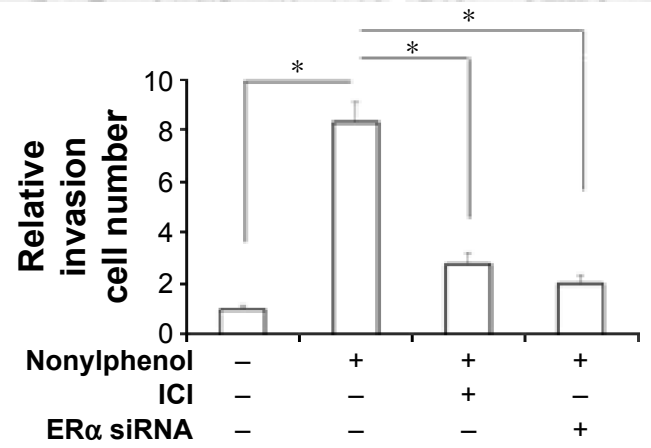

Figure 7 Effect of estrogen and ER $\alpha$ on in vitro invasion of SH-SY5Y cells.

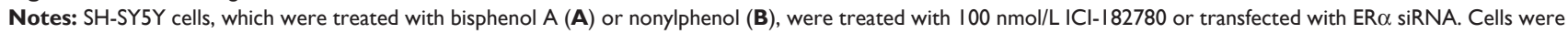
then measured by transwell assays. Invasion cells are shown in the photographs. Data are mean $\pm \mathrm{SD}$ of triplicate independent experiments with similar numbers. $* P<0.05$. Abbreviations: $\mathrm{ER} \alpha$, estrogen receptor $\alpha$; siRNA, small interfering RNA; DMSO, dimethyl sulfoxide; ICl, ICl- 182780 .

stimulation of proliferation of cancerous cells requires some agonist, such as E2. This work provides the clue that bisphenol $\mathrm{A}$ and nonylphenol mediated the proliferation of neuroblastoma cells via activating ER $\alpha$. It is valuable to decipher the effect of bisphenol A and nonylphenol on ETS-1 activity in future.

It is well known that $\mathrm{ER} \alpha$ and $\mathrm{ER} \beta$ share considerable sequence homology yet exert opposite effects on the proliferation or metastasis of endocrine cancers. ${ }^{2,3}$ While the roles of ER $\alpha$ in breast tumors or ovarian cancer have been characterized, further research still needed to identify the function and mechanisms of ER $\alpha$ in neuroblastoma. In this work, transcription factor activity of ER $\alpha$ activation upon nonylphenol A or bisphenol treatment enhances the proliferation and metastasis of neuroblastoma cell $\mathrm{SH}-$ SY5Y, an ER $\alpha$-positive and ER $\beta$-negative cell line. These data extend our knowledge for ER $\alpha$ ectopic or aberrant activation in neuroblastoma development. At the same 
A Solvent control: DMSO

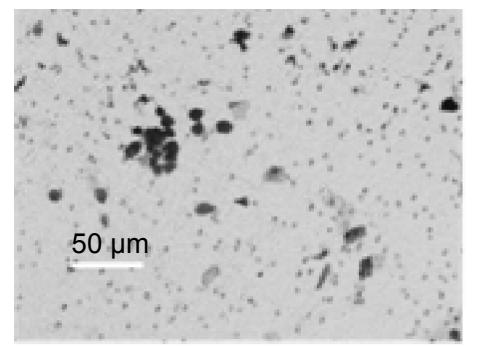

Bisphenol A + ER $\alpha$ siRNA

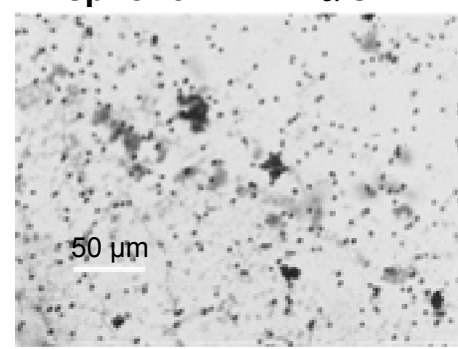

B Solvent control: DMSO

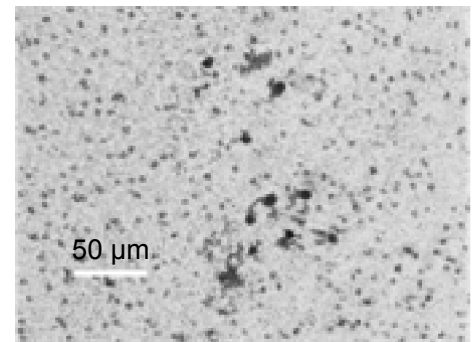

Nonylphenol + ER $\alpha$ siRNA

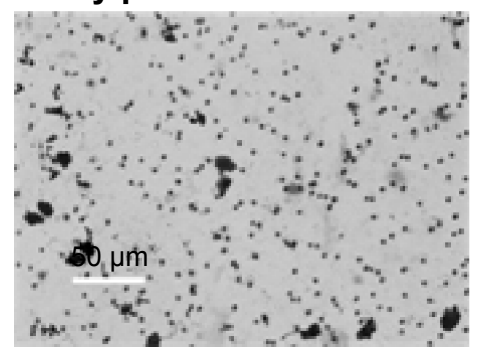

Bisphenol A

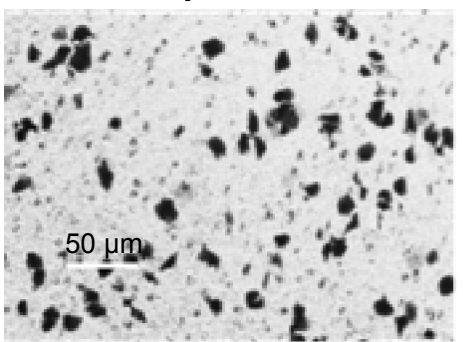

Bisphenol A + ICl-182780
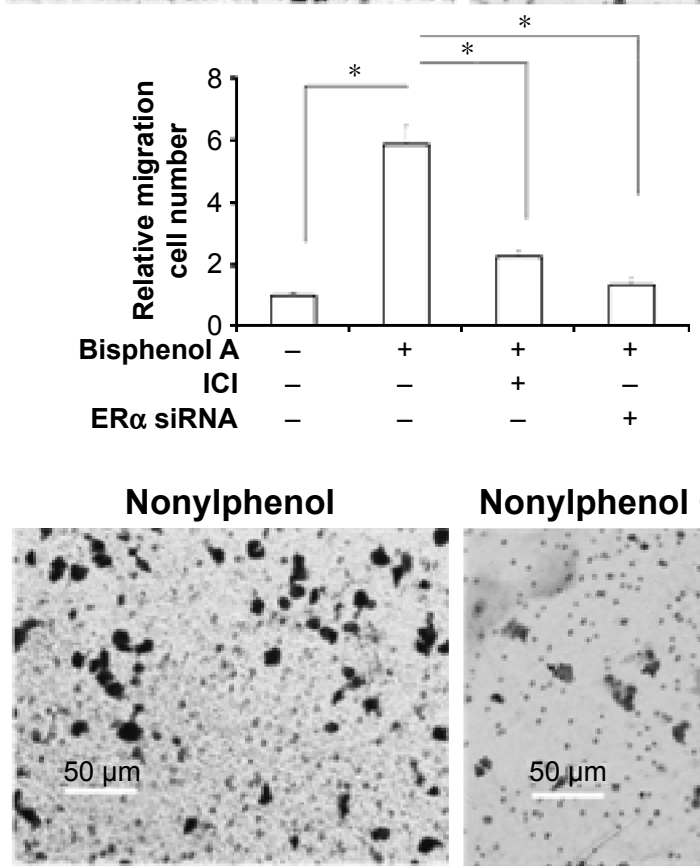

Nonylphenol + ICl-182780

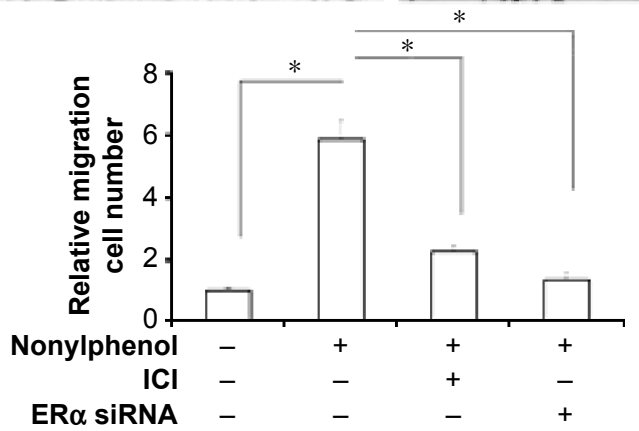

Figure 8 Effect of estrogen and $\mathrm{ER} \alpha$ on in vitro migration of SH-SY5Y cells.

Notes: SH-SY5Y cells, which were treated with bisphenol A (A) or nonylphenol (B), were treated with I00 nmol/L ICl-I82780 or transfected with ER $\alpha$ siRNA. Cells were then measured by transwell assays. Migration cells are shown in the photographs. Data are mean \pm SD of triplicate independent experiments with similar numbers. $* P<0.05$.

Abbreviations: $\mathrm{ER} \alpha$, estrogen receptor $\alpha$; siRNA, small interfering RNA; DMSO, dimethyl sulfoxide; ICI, ICI-I82780.

time, Zhu et $\mathrm{al}^{26,27}$ showed that bisphenol would promote the proliferation of SK-N-SH cells (ER $\beta$ positive and ER $\alpha$ negative) via ER $\beta$. The proliferative role of ER $\beta$ upon bisphenol treatment would not be a common phenomenon and needed further studies. Moreover, Kudo et $\mathrm{al}^{28}$ also reported that nonylphenol induces the death of neural stem cells and regulation of the cell cycle. This situation would be due to cell type specificity, that is, ER $\alpha$ negative or deleted. ${ }^{28}$
Proliferation and metastasis are the main features of cancer cells, which are also markers for cancer progression evaluation. Recent discoveries showed that chemicals would participate in the regulation of proliferation of cancer cells. ${ }^{1-5}$ Suffering aggravation of environmental contamination, a major public health concern, is the potential disruption of normal endocrine function and the progress of endocrinerelated cancer caused by interactions between chemicals and ER $\alpha .{ }^{1-3}$ EDCs, which are categorized as a high production 
volume chemical, are used in the manufacture of therapeutic agents, industrial chemicals, environmental pollutions, pesticides, and other chemicals. ${ }^{2-4}$ Bisphenol A and a similar chemical Bisphenol AF (BPAF), which are widely used in the manufacturing of polycarbonate plastics and as nonpolymer additive to other plastics, can be found in food, drinks, or beverages, and the environment has been measured in adult fetal serum. ${ }^{1-4} 4-n$-Nonylphenol is also found in food. ${ }^{1-5}$ Consistent with these findings, our results revealed that bisphenol $\mathrm{A}$ and nonylphenol can alter cell division and may be involved in neuroblastoma progression. Studying the correlation of EDCs and neuroblastoma by oncoepidemiological research would be beneficial for further pharmaceutical treatment.

Moreover, MCF-7, a typical breast cancer cell line, was also used to study estrogen action..$^{29,30}$ However, there is no available model for endocrine-related cancer besides breast cancer. Our work established a neuroblastoma cell model for measuring the prometastasis ability of EDCs. Moreover, there are some in vivo assays measuring the effect of EDCs in bone, cardiovascular, breast, or uterine tissues. ${ }^{30}$ Thus, it is valuable to establish the in vivo model measuring prometastasis ability of EDCs in endocrine-related cancer in the future.

\section{Conclusion}

In summary, EDCs are involved in the proliferation or metastasis and would be a potential biomarker or risk factor in the prognosis of neuroblastoma. This notion is supported by the fact that bisphenol A and nonylphenol promoted the proliferation and metastasis of neuroblastoma cells via enhancing the activity of ER $\alpha$. These findings would help us understand more about the interaction of EDCs and ER $\alpha$ in endocrine-related cancer.

\section{Acknowledgments}

We thank Doctor Qinong Ye at the Institute of Biotechnology, Chinese Military Medical Science Academy, for reagents and helpful discussions, and Doctor Yu Cao at the Georgia Regents University and Professor Li-Li Wang at the Institute of Toxicology and Pharmacology, Chinese Military Medical Science Academy, for important advices. This work was supported by the Key Scientific and Technological Research Foundation of China (2013ZX09J13109-03B).

\section{Author contributions}

All authors made substantial contributions to the design and conception; acquisition, analysis or interpretation of data. Authors took part in either drafting or revising the manuscript. At the same time, authors gave final approval of the version to be published; and agree to be accountable for all aspects of the work in ensuring that questions related to the accuracy or integrity of any part of the work are appropriately investigated and resolved.

\section{Disclosure}

The authors report no conflicts of interest in this work.

\section{References}

1. Zhang F, Feng F, Yang PX, et al. Four-and-a-half-LIM protein 1 down-regulates estrogen receptor $\alpha$ activity through repression of AKT phosphorylation in human breast cancer cell. Int J Biochem Cell Biol. 2012;44(2):320-326.

2. Yuan B, Cheng L, Chiang HC, et al. A phosphotyrosine switch determines the antitumor activity of ER $\beta$. J Clin Invest. 2014;124(8): 3378-3390.

3. Cheng L, Li JP, Han YJ, et al. PES1 promotes breast cancer by differentially regulating $\mathrm{ER} \alpha$ and $\mathrm{ER} \beta$. J Clin Invest. 2012;122(8): 2857-2870.

4. Chai J, Lee KF, Ng EH, Yeung WS, Ho PC. Ovarian stimulation modulates steroid receptor expression and spheroid attachment in peri-implantation endometria: studies on natural and stimulated cycles. Fertil Steril. 2011;96(3):764-768.

5. Egloff AM, Rothstein ME, Seethala R, Siegfried JM, Grandis JR, Stabile LP. Cross-talk between estrogen receptor and epidermal growth factor receptor in head and neck squamous cell carcinoma. Clin Cancer Res. 2009;15(21):6529-6540.

6. Lovén J, Zinin N, Wahlström T, et al. MYCN regulated microRNAs repress estrogen receptor-alpha (ESR1) expression and neuronal differentiation in human neuroblastoma. Proc Natl Acad Sci U S A. 2010; 107(4):1553-1558.

7. Garcia-Segura LM, Sanz A, Mendez P. Cross-talk between IGF-I and estradiol in the brain: focus on neuroprotection. Neuroendocrinology. 2006;84(4):275-279.

8. Ryu NG, Moon IJ, Chang YS, et al. Cochlear implantation for profound hearing loss after multimodal treatment for neuroblastoma in children. Clin Exp Otorhinolaryngol. 2015;8(4):329-334.

9. Al-Tonbary Y, Badr M, Mansour A, et al. Clinico-epidemiology of neuroblastoma in north east Egypt: a 5-year multicenter study. Oncol Lett. 2015;10(2):1054-1062.

10. Shao JB, Lu ZH, Huang WY, Lv ZB, Jiang H. A single center clinical analysis of children with neuroblastoma. Oncol Lett. 2015;10(4): 2311-2318

11. Cao P, Feng F, Dong GF, et al. Estrogen receptor $\alpha$ enhances the transcriptional activity of ETS-1 and promotes the proliferation, migration and invasion of neuroblastoma cell in a ligand dependent manner. $B M C$ Cancer. 2015;15:491.

12. Henley DV, Korach KS. Physiological effects and mechanisms of action of endocrine disrupting chemicals that alter estrogen signaling. Hormones (Athens). 2010;9(3):191-205.

13. Li Y, Luh CJ, Burns KA, et al. Endocrine disrupting chemicals (EDCs): in vitro mechanism of estrogenic activation and differential effects on ER target genes. Environ Health Perspect. 2013;121(4):459-466.

14. Kim HS, Han SY, Yoo SD, et al. Potential estrogenic effects of bisphenol A estimated by in vitro and in vivo combination assays. $J$ Toxicol Sci. 2001;26(3):112-118.

15. Huang RL, Sakamuru S, Martin MT, et al. Profiling of the Tox $2110 \mathrm{~K}$ compound library for agonists and antagonists of the estrogen receptor alpha signaling pathway. Sci Rep. 2014;4:5664.

16. Zhang LY, Sedykh A, Tripathi A, et al. Identification of putative estrogen receptor-mediated endocrine disrupting chemicals using QSAR- and structure-based virtual screening approaches. Toxicol Appl Pharmacol. 2013;272(1):67-76. 
17. Feng F, Wang LL. [Recognition of environmental estrogen-like compounds based on fluorescent imaging analysis of ER $\alpha$-EGFP nuclear granules formation]. Military Med Sci. 2015;39(1):12-17. Chinese.

18. Zhang H, Xie XY, Zhu XD, et al. Stimulatory cross-talk between NFAT3 and estrogen receptor in breast cancer cells. J Biol Chem. 2005; 280(52):43188-43197.

19. Yang Q, Feng F, Zhang F, et al. LINE-1 ORF-1p functions as a novel HGF/ETS-1 signaling pathway co-activator and promotes the growth of MDA-MB-231 cell. Cell Signal. 2013;25(12):2652-2660.

20. Zhao J, Bai Z, Feng F, et al. Cross-talk between EPAS-1/HIF-2 $\alpha$ and PXR signaling pathway regulates multi-drug resistance of stomach cancer cell. Int J Biochem Cell Biol. 2016;72:73-88.

21. Wang X, Cao P, Li Z, Wu D, Wang X, Liang G. EPAS-1 mediates SP-1-dependent FBI-1 expression and regulates tumor cell survival and proliferation. Int J Mol Sci. 2014;15(9):15689-15699.

22. Chen Y, Feng F, Gao X, et al. MiRNA153 reduces effects of chemotherapeutic agents or small molecular kinase inhibitor in HCC cells. Curr Cancer Drug Targets. 2015;15(3):176-187.

23. Ma D, Jia H, Qin M, et al. MiR-122 induces radiosensitization in non-small cell lung cancer cell line. Int J Mol Sci. 2015;16(9):22137-22150.
24. Qin H, Sha J, Jiang C, et al. miR-122 inhibits metastasis and epithelialmesenchymal transition of non-small-cell lung cancer cells. Onco Targets Ther. 2015;8:3175-3184.

25. Hui AM, Zhang W, Chen W, et al. Agents with selective estrogen receptor (ER) modulator activity induce apoptosis in vitro and in vivo in ER-negative glioma cells. Cancer Res. 2004;64(24):9115-9123.

26. Zhu H, Xiao X, Zheng J, Zheng S, Dong K, Yu Y. Growth-promoting effect of bisphenol A on neuroblastoma in vitro and in vivo. J Pediatr Surg. 2009;44(4):672-680.

27. Zhu H, Zheng J, Xiao X, et al. Environmental endocrine disruptors promote invasion and metastasis of SK-N-SH human neuroblastoma cells. Oncol Rep. 2010;23(1):129-139.

28. Kudo C, Wada K, Masuda T, et al. Nonylphenol induces the death of neural stem cells due to activation of the caspase cascade and regulation of the cell cycle. J Neurochem. 2004;88(6):1416-1423.

29. Teng C, Goodwin B, Shockley K, et al. Bisphenol A affects androgen receptor function via multiple mechanisms. Chem Biol Interact. 2013; 203(3):556-564.

30. Fuchs-Young R, Glasebrook AL, Short LL, et al. Raloxifene is a tissueselective agonist/antagonist that functions through the estrogen receptor. Ann N Y Acad Sci. 1995;761:355-360.
OncoTargets and Therapy

\section{Publish your work in this journal}

OncoTargets and Therapy is an international, peer-reviewed, open access journal focusing on the pathological basis of all cancers, potential targets for therapy and treatment protocols employed to improve the management of cancer patients. The journal also focuses on the impact of management programs and new therapeutic agents and protocols on

\section{Dovepress}

patient perspectives such as quality of life, adherence and satisfaction. The manuscript management system is completely online and includes a very quick and fair peer-review system, which is all easy to use. Visit http://www.dovepress.com/testimonials.php to read real quotes from published authors. 